\title{
Ammonia desorption from fly ash
}

\author{
Izabella Maj ${ }^{* 1}$, Sylwester Kalisz ${ }^{1}$, Waldemar Gądek ${ }^{1}$ \\ ${ }^{1}$ Silesian University of Technology, Institute of Power Engineering and Turbomachinery, Division of \\ Boilers and Steam Generators, Konarskiego 20, 44-100 Gliwice, Poland
}

\begin{abstract}
The main source of ammonia in ash are residues from an unreacted $\mathrm{NH}_{3}$ from the denitrification process, either from SCR or SNCR systems. The paper discusses the standards of $\mathrm{NH}_{3}$ content in fly ash and presents the most commonly used methods of removing excess ammonia from fly ash. In the next part of the work the results of laboratory tests on $\mathrm{NH}_{3}$ desorption are presented. Desorption was performed on samples of fly ash taken from the electrostatic precipitator of real PC boiler. Removal of $\mathrm{NH}_{3}$ from the ash was carried out in a heating chamber at $130^{\circ} \mathrm{C}$ and $150^{\circ} \mathrm{C}$ and detected by an analyser equipped with a NDIR sensor. Additionally, at the temperature of $130^{\circ} \mathrm{C}$, the NDIR and analytical methods were compared (in accordance with the BN-750541-05 procedure) and the measurement uncertainty of both methods was estimated.
\end{abstract}

\section{Introduction}

The utilization of fly ash for construction purposes, i.e. for the production of concrete, requires that the ash meet certain criteria for physical and chemical properties. The fly ash obtained from boilers equipped with a flue gas denitrification system contains a certain amount of ammonium compounds due to the so-called "slip" of ammonia. Ammonia binds directly to ash as an unreacted substrate of denitrification reactions. In the case of SCR and SNCR installations with significant $\mathrm{NH}_{3} / \mathrm{NO}$ molar excess, this leads to a substantial slip of $\mathrm{NH}_{3}$ to the exhaust gas and ash. Due to used method the sources of ammonia are [1,2]:

- $\mathrm{SCR}$ (selective catalytic reduction) - usually $\mathrm{NH}_{3}$ aqueous solution,

- SNCR (Select non-catalytic reduction) - usually a 40\% solution of $\mathrm{CO}\left(\mathrm{NH}_{2}\right)$ urea.

In an alkaline environment (concrete, mortar, etc.), ammonia is released to the atmosphere in molecular form. The presence of ammonium compounds in concrete does not

\footnotetext{
*Corresponding author: izabella.maj@polsl.pl,
} 
unfavorably affect on its properties, however, it is an undoubted trade disadvantage, especially when the concrete is used in closed rooms. Currently there are no official standards for the content of ammonia in fly ash in Poland. Depending on the specification of the test site (including ventilation, air conditioning), it was found that the smell of ammonia is not perceptible in the case of fly ash containing not more than 100 to $200 \mathrm{mg}$ $\mathrm{NH}_{3} / \mathrm{kg}$. It was assumed that the maximum ammonia content in ash should not exceed 100 $\mathrm{mg} \mathrm{NH}_{3} / \mathrm{kg}$ (U.S.A.), also lower values appear, up to $50 \mathrm{mg} \mathrm{NH}_{3} / \mathrm{kg}$ (Germany). Meanwhile, the ash from the SCR plant can contain up to $2500 \mathrm{mg} \mathrm{NH}_{3} / \mathrm{kg}$, which makes it unsuitable for use in the construction industry. Removing ammonia from fly ash would therefore be beneficial from the point of view of both the producer and the recipient.

The amount of ammonia and ammonium salts present in the fly ash is related to the amount of ammonia in the exhaust gas. According to the literature, up to $80 \%$ of ammonia from SCR is absorbed on fly ash [3]. Mostly, ammonia in fly ash occurs in the form of ammonium salts (mainly ammonium sulphate and ammonium bisulfate). There are also smaller amounts of other salts, such as ammonium chloride. In addition to the formation of ammonium salts, ammonia can also be adsorbed on the surface of ash particles, especially if the ash contains some unburned carbon. The reaction of carbon with ammonia takes place at a temperature of $200-400^{\circ} \mathrm{C}$ and leads to the binding of a functional group on the surface of coal [3]. The studies presented in [4] show that a sample of coal-containing ash is characterised by a greater adsorption of ammonia than a sample without carbon. In addition, it can be noticed that the carbon in ash shows a decrease in ammonia adsorption in increasing temperature, i.e. at a lower temperature, more ammonia passes to ash, less to gas phase [4].

\section{Methods of ammonia desorption from fly ash}

\subsection{Thermal methods}

Thermal methods of removing ammonia from ash are characterized by lower investment costs than chemical methods. Typically, these methods are based on desorption of ammonia at $300-450^{\circ} \mathrm{C}[5]$.

\subsubsection{ERC Method (Energy Research Center)}

In this method the ash from silo is placed into the fluidized bed reactor using air as fluidizing medium. During the process, the heated air flow continuously through the ash bed. Possible ash agglomerates are broken down by the acoustic method, through the waves generated by the acoustics generators. The method is used for ash with 500-1000 ppm concentration of ammonia. The release of ammonia starts at $150^{\circ} \mathrm{C}$ and the constant process temperature is $343-398^{\circ} \mathrm{C}$. The process allows removing up to $90 \%$ of ammonia. This technology is not currently used industrially and remains in the testing phase. An unquestionable disadvantage is the necessity of using sound systems to break up the ash agglomerates in the reactor. The ERC method tests concern ash with an ammonia content above $500 \mathrm{ppm}$, and there is no data on its efficiency for lower concentrations [6].

\subsubsection{Carbon Burnout}

In this method ash is fed into fluidized bed reactor were unburnt carbon in ash is burnout. The process takes place in a reactor at a temperature of about $700^{\circ} \mathrm{C}$ with a residence time of ashes in the reactor for 45 minutes. During combustion in high temperature ammonia 
compounds are decomposed. The process allows to obtain ash with an ammonia content below $5 \mathrm{ppm}$. In addition, the coal contained in the ash is burned (reduction of TOC), which improves its properties in terms of the use in construction. This method is used on a large scale in the U.S.A. [7].

\subsection{Chemical Methods}

\subsubsection{STI Method}

In solutions of ammonium salts with $\mathrm{pH}$ above 7, the ammonia is released into the gas phase. This is the basis of most chemical methods for removing ammonia from fly ash. Water injection to the ash causes the increase of its $\mathrm{pH}$ and thus the release of ammonia to the gas phase due to the neutralization of acidic residues which are formed with ammonia. This reaction takes place in the process of producing cement from ash [8].

In the STI method small amount of water with alkaline compounds is injected to the ash. Ammonia released from the ash is then catalytically reduced or removed in wet absorbers. In the STI process it is possible to reduce the mass fraction of ammonia in ash to a value below $100 \mathrm{ppm}$, which is the accepted limit of detection in construction products. The technology involves the use of water, which in itself causes the release of some of the ammonia to the gas phase, but the addition of alkaline compounds increases the efficiency of the process. According to [9], the addition of water is about $5 \%(<20 \%)$ and alkaline compounds about $5 \%(<10 \%)$. Moreover solution of $0.25-1 \% \mathrm{CaO}$ or $\mathrm{Ca}(\mathrm{OH})_{2}$ is dosed. The process takes place at a temperature of $15-65.5^{\circ} \mathrm{C}$ for 15 to 30 minutes.

\subsubsection{ASMTechnology}

The ASMTechnology method assumes the use of $\mathrm{Ca}(\mathrm{ClO})_{2}$ calcium hypochlorite as a strong oxidizing agent. The efficiency of this process is up to $95 \%$. Ammonia contained in the ash is oxidized to molecular nitrogen, additionally chlorine ions are released. The degree of removal of ammonia depends on the $\mathrm{pH}$ of the ash, time and temperature of the reaction and the amount of reagent used. In practice, 1.0-1.5 times the molar excess of calcium hypochlorite to ammonia is used [10].

\subsubsection{Ozonation}

The laboratory tests conducted in [11] show the results of ammonia removal from ash by ozone oxidation. The ash may have catalytic properties in the oxidation of ammonia with ozone at ambient temperature $\left(23{ }^{\circ} \mathrm{C}\right)$ [12]. In this process air with high humidity is supplied to the ash in the order to keep moisture of ash at level of 1-5\%. To the semi-dry ash obtained in this way, ozone, a mixture of air with ozone or oxygen and ozone as an oxidizing agent is supplied. Table 1 shows the results of the experiment for the initial $\mathrm{NH}_{3}$ content in ash of $1200 \mathrm{ppm}$. In each case, ozone caused a reduction of ammonia and the best result was obtained for a mixture of $2 \%$ ozone at $150{ }^{\circ} \mathrm{C}$. 
Table 1. Results of $\mathrm{NH}_{3}$ removing using ozonation [11].

\begin{tabular}{|c|c|}
\hline Oxidazing agent & $\begin{array}{c}\mathbf{N H}_{\mathbf{3}} \text { concentration in ash } \\
\text { after process, } \mathbf{p p m}\end{array}$ \\
\hline $\mathrm{O} 2\left(150^{\circ} \mathrm{C}\right)$ & 1200 \\
\hline $\mathrm{O} 34000 \mathrm{ppm}\left(20^{\circ} \mathrm{C}\right)$ & 850 \\
\hline $\mathrm{O} 34000 \mathrm{ppm}\left(150^{\circ} \mathrm{C}\right)$ & 500 \\
\hline $\mathrm{O} 32 \%$ obj. $\left(150^{\circ} \mathrm{C}\right)$ & 400 \\
\hline
\end{tabular}

\subsubsection{Catalitic Methods}

These methods are based on the reaction of selective catalytic oxidation of ammonia (SCO - selective catalytic oxidation) acc. reaction (1):

$$
4 \mathrm{NH}_{3}+3 \mathrm{O}_{2} \rightarrow 2 \mathrm{~N}_{2}+6 \mathrm{H}_{2} \mathrm{O}
$$

The different catalysts can be used in this process, for example: $\mathrm{CuO}, \mathrm{Fe}_{2} \mathrm{O}_{3}, \mathrm{Co}_{3} \mathrm{O}_{4}, \mathrm{MnO}$, $\mathrm{V}_{2} \mathrm{O}_{5}, \mathrm{CuO} / \mathrm{La}_{2} \mathrm{O}_{3}, \mathrm{CuO} / \mathrm{RuO}_{2}$. The best efficiency obtained is $60 \%$ conversion of ammonia to $\mathrm{N}_{2}$ with nitrogen selectivity over $90 \%$. The process temperature is $300-450^{\circ} \mathrm{C}$. The advantage of catalytic methods of ammonia removal is the ability to conduct the process in a stream of dusty exhaust gas, without the need to separate the ash. The disadvantage is the necessity of installing the catalyst and the possibility of its deactivation ("poisoning") by $\mathrm{SO}_{2}$ or heavy metals contained in the exhaust gas. Studies carried out so far assume the utilization of water vapour resistant catalysts [12-13].

\subsubsection{Wet Methods}

Studies on the solubility of ammonium compounds show that after 10 minutes of aqueous extraction, about $85 \%$ of ammonia is released from ash into water. In this process ammonia is removed in fluidized reactor in contact with high humidity air or by rinsing of dusted exhausts in a reactor with strongly turbulent flow. This allows removing from the flue gas ash particles up to $0.5 \mu \mathrm{m}$ as well as gaseous components soluble in water, including $\mathrm{NH}_{3}$ [14-16].

\section{Methodology}

For experiments the fly ash was separated from the electrostatic precipitator of a coal-fired pulverized coal boiler. In the order to increase ammonia concentration in ash, the ash were extra enriched by gaseous ammonia. Because the initial content of ammonia in the ash was less than $50 \mathrm{mgNH}_{3} / \mathrm{kg}$. The increase of ammonia content in ash sample were achieved using the $\mathrm{NH}_{3}$ gas stream supplied from the bottle. This value was increased to $453 \mathrm{mg}$ $\mathrm{NH}_{3} / \mathrm{kg}$. An ash sample of $200 \mathrm{~g}$ was placed in a flat crucible in a constant temperature zone in a closed heating chamber. The air flow through the chamber was set at $2 \mathrm{dm}^{3} / \mathrm{min}$ and controlled by the flow regulator according to Figure 1. 


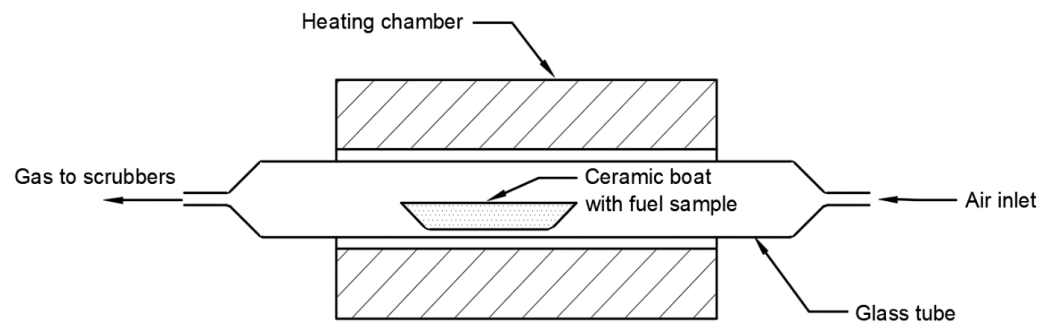

Fig 1. Scheme of the lab facility.

The test were conducted at two temperatures: $130^{\circ} \mathrm{C}$ and $150^{\circ} \mathrm{C} . \mathrm{NH}_{3}$ content in outlet of combustion chamber were measured by two methods:

- Using the SIEMENS U6 gas analyser, equipped with NDIR (Non Dispersive Infrared Sensor) $\mathrm{NH}_{3}$ sensor. This gas analyser is dedicated for $\mathrm{NH}_{3}$ measurements in two ranges $0-100 \mathrm{ppm}$ vol. and $0-1000 \mathrm{ppm}$ vol. The gas sample flowing through the analyser must be adequately dedusted (particles $\mathrm{d}_{\mathrm{z}}<1 \mu \mathrm{m}$ ) and dried. For this purpose, it is possible to use an exhaust gas conditioning system using a Peltier cell, which allows quick water condensation from the exhaust gas and its immediate removal. However, one should remember about the possibility of $\mathrm{NH}_{3}$ being absorbed in the removed condensate, which may lower the real values of the measured $\mathrm{NH}_{3}$.

- Using the standardized procedure BN-75 0541-05. This method can be used for determination of ammonia content in gaseous fuels and crude (raw) gases from combustion of carbon origin fuels. Is used in the determination of ammonia regardless of its content in the gas. The method is based on the quantitative absorption of ammonia in a solution of sulfuric acid. The excess sulfuric acid is back-titrated with the standard solution of sodium hydroxide. Apparatus, instruments and reagents used to measure:

- Two gas scrubbers with a capacity of $200 \mathrm{~cm} 3$ each, including one with a filter

- Laboratory gas meter

- Sulfuric acid solution $0.01 \mathrm{~N}$

- Sodium hydroxide solution $0.01 \mathrm{~N}$

- Methyl red (alcoholic solution).

The scrubbers contain of $0.01 \mathrm{~N}$ sulfuric acid solution of $60 \mathrm{~cm}^{3}$ and $1 \mathrm{~cm}^{3}$ of methyl red alcohol solution. The apparatus has been set up so that the gas flow path to the scrubbers is as short as possible and all connections are sealed. After the gas was bubbled through the scrubbers, the solution from scrubbers 1 and 2 was quantitatively transferred to a flask and the excess of $0.01 \mathrm{~N}$ sulfuric acid solution was titrated with $0.01 \mathrm{~N}$ sodium hydroxide solution.

Ammonia content in the gas $\mathrm{X}$ is calculated as $\mathrm{gNH}_{3} / 100 \mathrm{~m}^{3}$ of gas according to:

where:

$$
X=\frac{0,01713(a-b) 10^{5}}{V_{o}}=\frac{1703(a-b)}{V_{o}}
$$

$\mathrm{a}$ - volume of $0,01 \mathrm{~N}$ sulfuric acid solution, $\mathrm{cm}^{3}$

$\mathrm{b}$ - volume of $0,01 \mathrm{~N}$ sodium hydroxide solution, $\mathrm{cm}^{3}$

$\mathrm{V}_{\mathrm{o}}$ - volume of gas, $\mathrm{cm}^{3}$

0,01713 - amount of ammonia corresponding to $1 \mathrm{~cm}^{3} 0,01 \mathrm{~N}$ sulfuric acid solution. 


\subsection{Measurement uncertainty}

An account of measurement uncertainties should be a part of every correctly performed experiment, especially when comparing different measurement methods of the same value in an indirect way. The determination of measurement uncertainty has a significant impact on the formulation of correct and reliable measurement conclusions [17]. In the power industry, the determination of measurement uncertainty may also be related to compliance with emission standards [18]. Expanded uncertainty is the most widely used method when it comes to industrial installations measurements. In the presented study, calculations of the expanded uncertainty with the extension coefficient $\mathrm{k}=2$ for the $95 \%$ confidence level were presented. The accuracy of the $\mathrm{NH}_{3}$ measurement by the analytical method consists of all the solutions volumes measurements, the subjective assessment of the color change of the solution, as well as the measurement uncertainty of the gas sampling device. When using the Siemens Ultramat U6 analyzer, Table 2 presents the parameters influencing the measurement result, which are provided by the manufacturer [19].

Table 2. The influence of different parameters on the measurement results of the Siemens U6 gas analyzer.

\begin{tabular}{|c|c|}
\hline \multicolumn{2}{|c|}{ Measurement quality } \\
\hline The output sygnal change & $\begin{array}{l}<+/-1 \% \text { smallest possible measurement, } \\
\text { range according to the nameplate with a } \\
\text { specific damping constant for the analyzer } \\
\text { (corresponding to }+/-0,33 \% \text { with } 2 \sigma \text { ) }\end{array}$ \\
\hline Zero drift & $<+/-1 \%$ measuremnt range / week \\
\hline Range drift & $<+/-1 \%$ measuremnt range / week \\
\hline Repeatability & $\begin{array}{l}\text { Between } 0,1 \% \text { annd } 1 \% \text { depending on the } \\
\text { model }\end{array}$ \\
\hline Linearity deviation & $<0,5 \%$ full scale value \\
\hline \multicolumn{2}{|c|}{ Influencing variables } \\
\hline Temperature & $\begin{array}{l}1 \% \text { measurement range } / 10 \mathrm{~K} \\
\text { (unheated version) }\end{array}$ \\
\hline The pressure of the measuring gas & $\begin{array}{l}\text { With pressure compensation } \\
<0,15 \% \text { of the setpoint; with } 1 \% \text { change } \\
\text { under pressure }\end{array}$ \\
\hline The stream of the measuring gas & Not important \\
\hline Power supply & $\begin{array}{c}<0,1 \% \text { range of the output signal at the rated } \\
\text { voltage }+/-10 \%\end{array}$ \\
\hline Ambient conditions & $\begin{array}{l}\text { It depends on the type of gas uptake: If it } \\
\text { contains a measured component or contains a } \\
\text { component that affects cross-sensitivity }\end{array}$ \\
\hline
\end{tabular}

\section{Experimental results}

Table 3 shows the amount of $\mathrm{NH}_{3}$ released from the ash after 10, 20, 30, 60 and 120 minutes of desorption at $130^{\circ} \mathrm{C}$ and $150^{\circ} \mathrm{C}$. The amount of $\mathrm{NH}_{3}$ (in $\mathrm{mg} \mathrm{NH}_{3}$ ) was calculated from the Siemens U6 analyzer measurement and presented and as a percentage of the initial $\mathrm{NH}_{3}$ content in the ash sample. The concentration of $\mathrm{NH}_{3} \mathrm{ppm}$ vol. as a function of experiment time is shown (Figure 2). A visible effect of temperature on the release rate of 
$\mathrm{NH}_{3}$ from ash can be observed. The initial concentration of $\mathrm{NH}_{3}$ at $130 \square \mathrm{C}$ was $710 \mathrm{ppm}$ vol. whereas at $150 \square \mathrm{C}$ it was $858 \mathrm{ppm}$ vol. Stabilization of desorption was obtained at $130 \square \mathrm{C}$ after 3 hours and 12 minutes, while at $150^{\circ} \mathrm{C}$ the time was shorter - 2 hours and 37 min. Further maintenance of the samples in the heating chamber did not affect the $\mathrm{NH}_{3}$ concentration in the outlet gas.

Table 3. Amount of $\mathrm{NH}_{3}$ released from the ash after 10, 20, 30, 60 and 120 min of desorption measured using the U6 analyzer.

\begin{tabular}{|c|c|c|c|c|}
\hline & \multicolumn{2}{|c|}{$130^{\circ} \mathrm{C}$} & \multicolumn{2}{c|}{$150^{\circ} \mathrm{C}$} \\
\hline Reaction time, $\min$ & $\mathrm{mg} \mathrm{NH}_{3}$ & $\%$ initial value & $\mathrm{mg} \mathrm{NH}_{3}$ & $\%$ initial value \\
\hline 10 & 15 & 16 & 17 & 19 \\
\hline 20 & 27 & 30 & 29 & 32 \\
\hline 30 & 37 & 41 & 38 & 42 \\
\hline 60 & 54 & 59 & 59 & 65 \\
\hline 120 & 71 & 78 & 80 & 88 \\
\hline
\end{tabular}

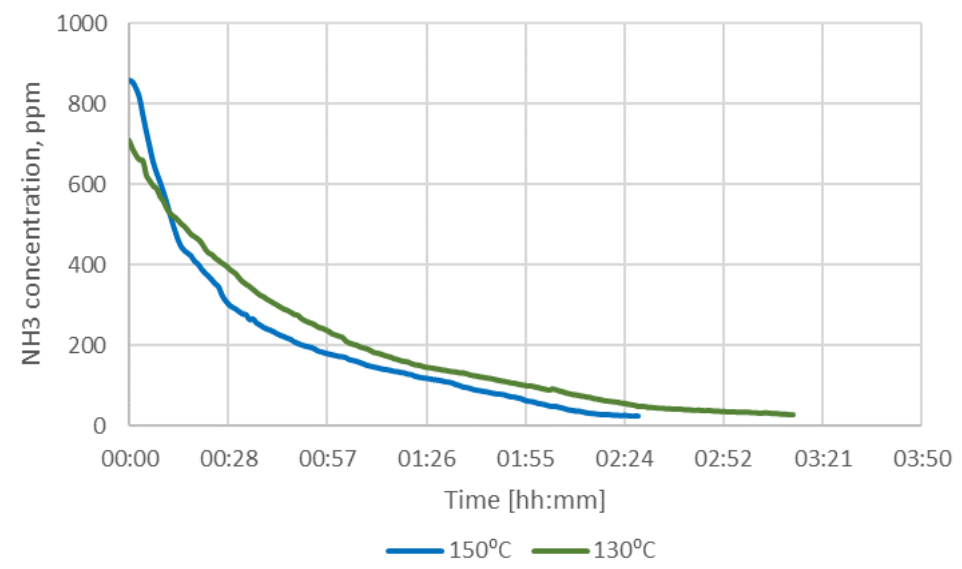

Fig 2. Concentration of $\mathrm{NH}_{3}$ at the outlet of the heating chamber for the desorption process at $130^{\circ} \mathrm{C}$ and $150^{\circ} \mathrm{C}$

For a more accurate analysis of the ammonia desorption process, the data presented in the Figure 3 was calculated. The rate of $\mathrm{NH}_{3}$ concentration decrease $\mathrm{ppm} / \mathrm{min}$ was calculated. This data shows that for the temperature of $150 \square \mathrm{C}$ the maximum rate of $43 \mathrm{ppm} \mathrm{NH} 3 / \mathrm{min}$ was reached after about 3 minutes, whereas for the temperature $130 \square \mathrm{C}$ it was $36 \mathrm{ppm}$ $\mathrm{NH} 3 /$ min after a time of about 4 minutes. At a higher temperature level $\left(150^{\circ} \mathrm{C}\right)$ the process takes place more rapidly. The significant drop in the concentration of $\mathrm{NH}_{3} / \mathrm{min}$ $\left(\geq 10 \mathrm{ppm} / \mathrm{min}\right.$ ) at $150^{\circ} \mathrm{C}$ takes place during the first 36 minutes of experiment, while for temp. $130^{\circ} \mathrm{C}$ for $31 \mathrm{~min}$.

In the further part of the study, the analytical method of $\mathrm{NH}_{3}$ measurement (in accordance with the BN-75 procedure 0541-05) was compared with the U6 analyzer. The values were converted into an amount of $\mathrm{NH}_{3}$ released into air and the percentage value of the initial NH3 content in the ash sample. In Figure 3 a comparison of the $\mathrm{NH}_{3}$ amount released from ash after $10,20,30$ and 60 minutes of desorption at $130^{\circ} \mathrm{C}$ is shown. 


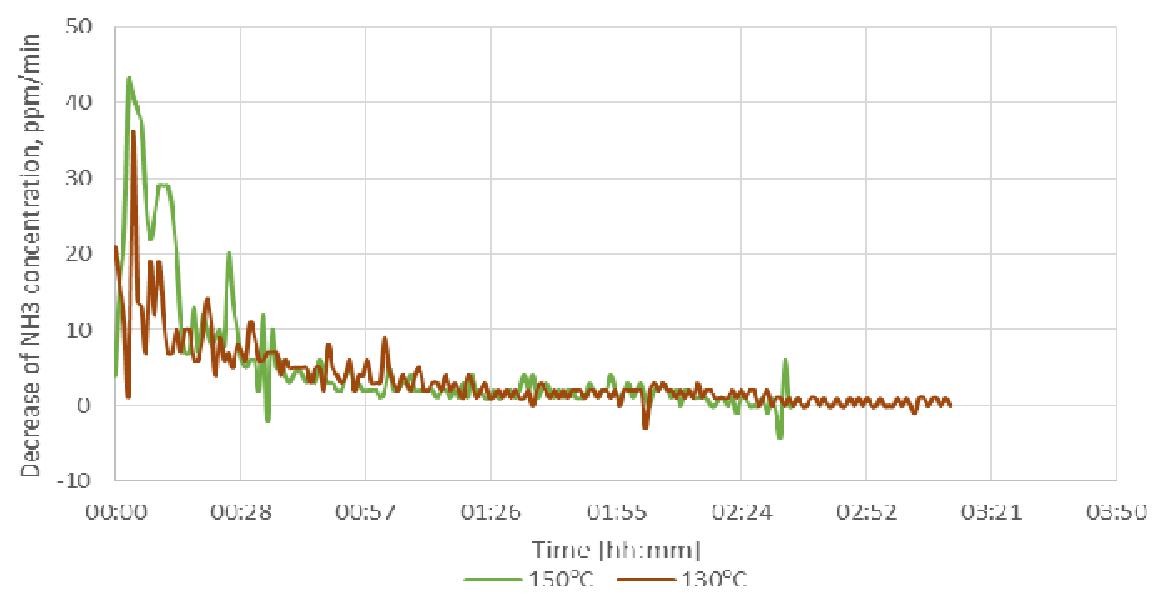

Fig 3. Decrease of $\mathrm{NH}_{3}$ concentration during desorption process at $130{ }^{\circ} \mathrm{C}$ and $150{ }^{\circ} \mathrm{C}$.

For a more detailed analysis, the uncertainty account was made using the extended uncertainty method with the extension coefficient $\mathrm{k}=2$ for the $95 \%$ confidence level. The uncertainty for the analytical method was $+/-18.9 \%$ of the released amount of $\mathrm{NH}_{3}$, while for the U6 analyzer it was $+/-9.25 \%$. It can concluded that the U6 analyzer measurement is almost twice as accurate as the method presented in the analytical method. However, this result is influenced by a small population of samples for both discussed methods. In all cases, the lower values obtained by the analytical method indicate that the absorption of $\mathrm{NH}_{3}$ in the condensed water (moisture from air and ash) removed in the exhaust conditioner had a little effect on the result of the U6 analyzer. Only in the lowest measured range after 10 minutes, similar values were obtained for $130{ }^{\circ} \mathrm{C}\left(14\right.$ and $\left.15 \mathrm{mgNH}_{3}\right)$ within the limits of measurement uncertainty. In the remaining time ranges, the values of the released $\mathrm{NH}_{3}$ do not differ significantly.

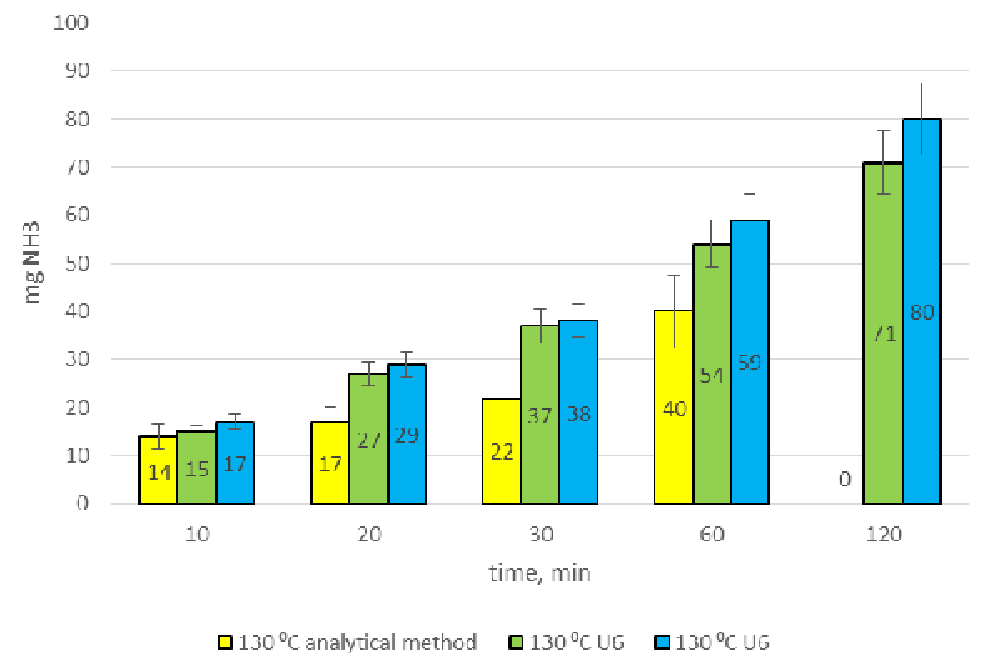

Fig 4. Amount of $\mathrm{NH}_{3}$ released from ash at $130^{\circ} \mathrm{C}$ for two measuring methods (U6 and analytical metric) and at $150^{\circ} \mathrm{C}(\mathrm{U} 6$ analyzer) with measured uncertainties. 


\section{Conclusions}

Desorption of ammonia from fly ash is an important process that can be applied in industry. It is mainly related to meeting the fly ash quality standard required by customers from the civil engineering industry. In presented research $\mathrm{NH}_{3}$ desorption was carried out from fly ash taken from the electrostatic precipitator from coal fired power plant. The experimental part of the research presents the results of ammonia desorption form ash placed in the heating chamber. The desorption was carried out at two temperature levels: $130{ }^{\circ} \mathrm{C}$ and 150 ${ }^{\circ} \mathrm{C}$. For the $130{ }^{\circ} \mathrm{C}$ two measuring methods were compared: the analytical method (according to polish standard BN-75 0541-05) and the Siemens U6 gas analyzer with NDIR sensor. The uncertainty analysis shows nearly 2 times greater accuracy of measurements using an NDIR analyzer comparing to the analytical method. The ammonia desorption from the ash is a rapid process in the first phase (30 minutes). The release of gaseous $\mathrm{NH}_{3}$ can be dangerous for people working with the power installation, as well as people who collect and transport the ash. The measurements made with the U6 analyzer indicate that for the first 30 minutes $41-42 \%$ of the initial value of $\mathrm{NH}_{3}$ contained in the ash is released, after $60 \mathrm{~min}$ it is $59-65 \%$, and after 120 minutes it is $78-88 \%$, depending on the process temperature $\left(130{ }^{\circ} \mathrm{C}-150{ }^{\circ} \mathrm{C}\right)$. Stabilization of the $\mathrm{NH}_{3}$ concentration was observed after 3 hours and 12 minutes for a temperature of $130{ }^{\circ} \mathrm{C}$, while for a temperature of $150{ }^{\circ} \mathrm{C}$ it was 2 hours and 37 minutes. Further research should take into account the influence of other ash compounds, its elemental composition and the size of the particles on the $\mathrm{NH}_{3}$ desorption process. The SEM-EDS analysis of the tested samples would be a purposeful addition.

\section{Acknowledgements}

The research was carried out as part of the project "Process optimisation and valorisation of combustion by-products in transition to circular economy (UPS-Plus)" (www.ccf.polsl.pl) financed by the TEAM-TECH Core Facility by Foundation for Polish Science. The research was co-financed as part of the BKM/561/RIE5/2017 project carried out at the Silesian University of Technology.

\section{References}

1. J. Sorrels et al.:Air Pollution Control Cost Manual Chapter 2: Selective Catalytic Reduction Air Economics Group Health and Environmental Impacts Division, U.S. Environmental Protection Agency (2016)

2. Y. Gao, X. Chen, G. Fujisaki, A. Mehta, E. Suuberg, R. Hurt.: Dry and Semi- Dry Methods for Removal of Ammonia from Pulverized Fuel Combustion Fly Ash, Energy and Fuels, 16, 1398-1404 (2002)

3. G. Brendel, J. Bonetti, R. Rathbone, R. Frey Jr.: Investigation of ammonia adsorption on fly ash due to installation of selective catalytic reduction systems. United States: N. p., Web. (2000)

4. In. Külaots, Y. Gao, R. Hurt E.. Suuberg: Adsorption of Ammonia on Coal Fly Ash. International Ash utilization Symposium, Center of Applied Energy Research, University of Kentucky (2011)

5. M. Mazur, T. Janda, W. Żukowski: Chemical and thermal methods for removing ammonia from fly ashes. Tech.1 Trans. Chem. (2017) 
6. R. Conn, N. Sarubac, E. Levy, Removing ammonia from fly ash, Lehigh energy update, 2 (2001)

7. S. Kirkconnell, J. Keppeler., Carbon Burn-Out ${ }^{\mathrm{TM}}$ - A State of the Art in Commercial Ash Beneficiation, PMI Ash Technologies SVP named new American Coal Ash Association Chair

8. D. 'Connor: Ammonia Removal from Fly Ash: Process Review - Separation Technologies LLC (ST) - Ammonia Removal Process, EPRI, Palo Alto (2007)

9. S. Gąsiorowski, F. Hrach, Method for Removing Ammonia from Ammonia Contaminated Fly Ash, Patent US6077494 (2000)

10. Ammonia Removal from Fly Ash: Process Review, Headwaters Ammonia Slip Mitigation (ASM ${ }^{\mathrm{TM}}$ ) Technology (www.epri.com), EPRI Project Manager D. O’Connor, Technical Update (2005)

11. R. Kastner, Catalytic ozonation of ammonia using biomass char and wood fly ash, Chemosphere 75,739-744 (2009)

12. S. Shresthaa, M. Harolda, K. Kamasamudramb, A. Kumarb, L. Olssonc, K. Leistnerc: Selective oxidation of ammonia to nitrogen on bi-functional $\mathrm{Cu}-\mathrm{SSZ}-13$ and Pt/Al2O3 monolith catalyst, Catalysis Today 267,130-144 (2016)

13. L. Chmielarz, A. Węgrzyn, M. Wojciechowska, S. itkowski, M. Michalik, Selective Catalytic Oxidation (SCO) of Ammonia to Nitrogen over Hydrotalcite Originated $\mathrm{Mg}-\mathrm{Cu}-\mathrm{Fe}$ Mixed Metal Oxides, Catalysis Letters, 141, 1345-1354 (2011)

14. A. Mehta., H. Hurt, Y. Gao, X. Chen, E. Suuberg Dry and Semi-dry methods for removal of ammonia from fly ash, Patent US6746654 B2, (2004)

15. H. Wang, H. Ban, D. Golden, K. Ladwig, Ammonia release characteristic from coal combustion fly ash, Fuel Chemistry Division Preprints, 47, 810 (2002)

16. C. Cardone, A. Kim, K. Schroeder, Release of ammonia from SCR/SNCR fly ashes, World of Coal Ash (WOCA) (2005)

17. R. Urba Niepewność pomiaru fizykochemicznych czynników środowiskowych w zakładach górnictwa nafty i gazu. Nafta-Gaz, 7, 573 - 576 (2010) http://archiwum.inig.pl/inst/nafta-gaz/nafta-gaz/Nafta-Gaz-2010-07-04.pdf access (21.09.2018)

18. A. Mainka, E. Głowacki, A. Gołębiowski.: System monitoringu zanieczyszczeń: O niepewności pomiaru. Energetyka Cieplna i Zawodowa, 5/2010. https://www.energopomiar.com.pl/publikacje/Art ZO niepewnosc pomiaru 2010 .pdf access (21.09.2018)

19. Siemens AG 1997 Automotion and Drivers, Manual Edition 11/2005 ULTRAMAT 6 and OXYMAT 6 Analyzers for IR-absorbing gases and oxygen. https://cache.industry.siemens.com/dl/files/737/23638737/att_90841/v1/Manual_U 1traoxymat6 A07 en 051214.pdf access (21.09.2018) 